Niniejsza publikacja jest dostępna na licencji Creative Commons. Uznanie autorstwa-Użycie niekomercyjne-Bez utworów zależnych 3.0 Polska. Pewne prawa zastrzeżone na rzecz autora. Zezwala się na wykorzystanie publikacji zgodnie z licencja - pod warunkiem zachowania niniejszej informacji licencyjnej oraz wskazania autora jako właściciela praw do tekstu. Treść licencji jest dostępna na stronie: http://creativecommons.org/licenses/by-nc-nd/3.0/pl/

Lingwistyka Stosowana 21: 1/2017, 23-37

\author{
Mirosław GAJER \\ AGH Akademia Górniczo-Hutnicza
}

\title{
Czy zagadkowy dysk z Fajstos w istocie zawiera odciśnięty w glinie zapis tekstu w pewnym języku naturalnym?
}

\begin{abstract}
:
Does the mysterious Phaistos disc really contain some natural language text stamped in the clay? The famous Phaistos Disc is an artifact that was found by the Italian archeologist L. Pernier in 1908 during the excavations in Crete. In the common opinion the Phaistos Disc contains a natural language text written with the use of some kind of a syllabic script. In order to test this assumption, a statistical analysis of the distribution of words' length of the Phaistos Disc was conducted. It proved that the A side and the B side of the Phaistos Disc differ considerably from each other. A comparison of the Phaistos disc inscription with the samples from modern Hebrew texts shows that such differences are not typical in the case of natural language texts in syllabic scripts. The findings suggest that it is highly possible that the Phaistos Disc does not contain any natural language text at all.
\end{abstract}

\section{Wstęp}

W dniu 3 lipca 1908 roku ekipa włoskich archeologów kierowana przez L. Perniera, podczas prowadzonych wykopalisk $\mathrm{w}$ ruinach minojskiego pałacu położonego na Krecie w miejscowości Fajstos, dokonała zdumiewającego odkrycia. Odnalezionym w trakcie prac wykopaliskowych artefaktem był niewielkich rozmiarów dysk wykonany z wypalonej gliny o średnicy około $16 \mathrm{~cm}$ i grubości około $2 \mathrm{~cm}$, który z obu stron pokryty był tajemniczymi znakami ułożonymi w formie spirali (zob. J. Chadwick 1998). Na podstawie kontekstu archeologicznego, do którego zalicza się między innymi glinianą tabliczkę zapisaną pismem linearnym A, dysk z Fajstos datowany jest w przedziale czasu od 1850 p.n.e. do 1600 p.n.e., aczkolwiek niektórzy badacze twierdzą, że jest on nieco młodszy i pochodzi z około XIV wieku p.n.e. (zob. W. Reczko 2009).

Najbardziej niezwykły wydaje się fakt, że znaki na dysku z Fajstos nie zostały w prosty sposób wyryte w miękkiej glinie, lecz były w niej odciśnięte za pomocą uprzednio przygotowanych $\mathrm{w}$ tym celu specjalnych stempelków. W związku z tym niektórzy badacze skłonni są uznać dysk z Fajstos za pierwszy znany w historii przykład tekstu drukowanego, z czego wynikałoby, że wynalazek druku został dokonany już ponad trzy tysiące lat przed Gutenbergiem (zob. A. Bradshaw 1977). 
Trudno jest wyobrazić sobie, aby ktoś zadał sobie spory trud przygotowania zestawu kilkudziesięciu stempelków w celu wytworzenia tylko i wyłącznie pojedynczego egzemplarza glinianego dysku, należałoby oczekiwać, że tego typu obiektów powinno w badanym obszarze kulturowym znajdować się znacznie więcej (zob. A. Kondratow 1988). Niestety, jak dotychczas archeologom w zasadzie nie udało się niczego podobnego do dysku z Fajstos odnaleźć. Jako pewnego rodzaju wyjątki podaje się niekiedy tzw. brązowy topór z Arkalochori oraz tzw. kamienny ołtarz z Mali - oba artefakty pochodzą również z Krety. Topór z Arkalochori został odnaleziony w 1934 roku na dnie groty, w której swego czasu odbywały się jakiegoś rodzaju obrzędy o charakterze mistycznym, i zawiera $\mathrm{w}$ sumie $\mathrm{w}$ trzech kolumnach wyryte piętnaście znaków, spośród których pięć wykazuje pewnego typu podobieństwo do znaków odciśniętych na dysku z Fajstos. Z kolei kamienny ołtarz z Mali datowany jest na rok około 1600 p.n.e. i zawiera w sumie szesnaście znaków wykutych w linii pionowej, przy czym w przypadku niektórych z nich można z pewnością doszukać się znacznych analogii ze znakami znanymi z dysku z Fajstos (zwłaszcza w przypadku znaku nr 14). Według niektórych badaczy to właśnie brązowy topór z Arkalochori oraz kamienny ołtarz z Mali stanowią podstawowe dowody przemawiające za autentycznością dysku z Fajstos i przemawiają za jego bezpośrednimi związkami ze starożytną kulturą minojską (zob. J. Ciechanowicz 1996). Obiektem często wymienianym w kontekście dyskusji związanych z dyskiem z Fajstos jest również tzw. złoty pierścień z Mavro Spelio odnaleziony w Konossos podczas prowadzonych tam prac archeologicznych w 1927 roku. Obiekt ten zawiera krótką inskrypcję w języku minojskim, składającą się z 19 znaków pisma linearnego A. Co charakterystyczne, znaki te zostały również ułożone w formie spirali, a cały napis należy czytać od brzegu spirali do środka.

Według dość powszechnie przyjętych w środowiskach naukowych opinii dysk z Fajstos zawiera na obu swych stronach jakiś bliżej nieokreślony tekst zapisany w pewnym języku naturalnym. Niestety, jak dotychczas wszelkie próby odczytania dysku z Fajstos zakończyły się całkowitym niepowodzeniem. Jednak wciąż nie brakuje wszelkiego typu amatorów, którzy co jakiś czas rozgłaszają za pośrednictwem mediów sensacyjne wieści, jakoby udało im się wreszcie dysk z Fajstos odczytać. Ponieważ uzyskane przez nich rezultaty najczęściej ocierają się mocno o granicę absurdu, tego rodzaju próby w środowiskach naukowych nie mogą być w żadnym wypadku traktowane poważnie (zob. Y. Duhoux 2000). Czegóż to zresztą z rozważanego dysku z Fajstos w przeszłości nie zdołano już wyczytać, włącznie z tajemnym przekazem pochodzącym z Atlantydy, przesłaniem dla ludzkości pochodzącym od jakiejś pozaziemskiej cywilizacji, hymnem na cześć bogini matki. Ktoś nawet kiedyś dopatrzył się odciśniętej na dysku swego rodzaju minojskiej wersji Kamasutry.

Ogłaszane co jakiś czas w mediach wyniki odczytania dysku z Fajstos są wzajemnie ze sobą całkowicie sprzeczne - zgodnie z zasadami elementarnej logiki zachodzić może tylko i wyłącznie jedna z dwóch wzajemnie wykluczających się możliwości. Mianowicie, albo jedna z propozycji odczytania dysku z Fajstos jest prawdziwa bądź w znacznym stopniu bliska jest prawdy, a pozostałe są z gruntu fałszywe, albo też wszystkie dotychczasowy próby odczytu dysku całkowicie mijają się z prawdą. Niestety, wiele wskazuje na to, że w przypadku ogłoszonych dotychczas prób odczytania 
dysku z Fajstos zdecydowanie ma miejsce druga z wymienionych możliwości.

Zresztą, prawdę powiedziawszy, nie mamy nawet pojęcia o tym, w jakim języku mógłby zostać zapisany dysk z Fajstos. Spośród potencjalnych kandydatów najczęściej wymieniany jest język grecki lub język minojski, o którym jak dotychczas wiemy w zasadzie bardzo niewiele, ponieważ pismo linearne A, w którym zachowały się jedynie bardzo krótkie inskrypcje o charakterze zapisów administracyjnych, wciąż pozostaje na razie w znacznej mierze nie odczytane. Ze względu na to, że dysk z Fajstos jest jak na razie swego rodzaju unikatem, niektórzy badacze wysuwają hipotezy, zgodnie z którymi zabytek ten nie jest wytworem cywilizacji minojskiej, ale został przywieziony na Kretę z jakiegoś bliżej nieokreślonego obszaru geograficznego. Za taką możliwością ma przemawiać dodatkowo fakt, że podobno ten rodzaj gliny, z której wypalono dysk z Fajstos, w ogóle nie występuje na Krecie (zob. A. Kondratow 1988). Takie postawienie sprawy w znaczący sposób poszerza krąg potencjalnych kandydatów, jeśli chodzi o możliwy język inskrypcji odciśniętej za pomocą stempelków na dysku. W takim wypadku proponuje się najczęściej jakiś język z rodziny języków semickich, ale także i sanskryt, język sumeryjski, hetycki, starożytny chiński, tybetański, różne języki drawidyjskie, a nawet język baskijski czy prasłowiański, żeby wymienić tylko niektóre $\mathrm{z}$ pojawiających się $\mathrm{w}$ tym obszarze propozycji, przy czym również zgłaszane są hipotezy o pochodzeniu dysku z obszaru starożytnej Anatolii i jego związkach z anatolijską grupą języków indoeuropejskich (zob. M. Popko 1999).

$\mathrm{Z}$ drugiej jednak strony istnieje pewna, aczkolwiek raczej nieliczna, grupa badaczy, którzy poddają w wątpliwość, czy dysk z Fajstos w ogóle zawiera jakikolwiek tekst zapisany w jakimkolwiek języku naturalnym. Jako rozwiązania alternatywne zwykle podają oni w tym względzie propozycje, zgodnie z którymi dysk z Fajstos jest swego rodzaju kalendarzem, stanowi zapis harmonogramu prac polowych i gospodarskich, jest obiektem o przeznaczeniu religijnym bądź magicznym i zawiera sekwencję modlitw, które należy odprawiać podczas obchodów pewnych uroczystości (zob. W. Reczko 2009). Można także spotkać się z hipotezą, w myśl której dysk z Fajstos jest planszą do gry. W takim wypadku zapewne należałoby poruszać się pionkiem po poszczególnych znakach odciśniętych na glinianym dysku wzdłuż linii spiralnej o liczbę pozycji równą na przykład liczbie oczek wyrzuconych na kostce, przy czym dokładne zasady leżące u podstaw takiej gry obecnie są zapewne już nie od odszyfrowania. Jedną z bardziej interesujących propozycji jest podejrzenie, iż dysk z Fajstos stanowi przykład swego rodzaju pseudo pisma. Znaczy to, że odciśnięty na nim ciąg znaków został wykonany przez osobę w ogóle nie umiejącą pisać w celu wytworzenia obiektu mającego w jakimś bliżej nieokreślonym celu jedynie udawać dokument pisany.

Z kolei w 2008 roku, czyli w stulecie odkrycia dysku z Fajstos, amerykański ekspert do spraw fałszerstw starożytnych dzieł sztuki, J. M. Eisenberg, opublikował artykuł, w którym przedstawił kontrowersyjną tezę, sprowadzająca się do tego, że dysk z Fajstos jest po prostu ordynarnym fałszerstwem, a ściślej rzecz ujmując, nazwał go wręcz stuletnim „wybrykiem” (zob. J. M. Eisenberg 2008). Według J. M. Eisenberga głównym podejrzanym jest sam L. Pernier, który, nie odnosząc na prowadzonych 
przez siebie stanowiskach archeologicznych żadnych większych sukcesów, najzwyczajniej zazdrościł A. Evansowi jego spektakularnych odkryć związanych z licznymi zabytkami pisanymi kultury minojskiej odkrytymi w ruinach pałacu w Knossos (były to gliniane tabliczki zapisane pismem linearnym A). Z tego powodu L. Pernier miałby dopuścić się fałszerstwa, najpierw fabrykując dysk z Fajstos, a następnie pozorując jego odnalezienie $\mathrm{w}$ trakcie prowadzonych przez kierowaną przez siebie ekipę prac wykopaliskowych. J. M. Eisenberg w wymienionym artykule przedstawił liczne argumenty na poparcie głoszonej przez siebie tezy, zwracając przede wszystkim uwagę na stylistyczną niejednorodność znaków odciśniętych na dysku z Fajstos, w przypadku których mamy wręcz do czynienia ze swoistym przemieszaniem stylów pochodzących z różnych epok i odrębnych obszarów kulturowych. Co ciekawe, greckie muzeum mieszczące się w Heraklionie na Krecie, w którym przechowywany jest obecnie w szklanej gablocie dysk z Fajstos, z zadziwiającym wręcz uporem wielokrotnie skutecznie odmawiało wydania rozważanego zabytku celem poddania go badaniom fizykochemicznym, które byłby w stanie potwierdzić bądź obalić jego autentyczność. Jako oficjalny powód przyjęcia tak nieugiętej postawy podawany jest przede wszystkim fakt, że dysk z Fajstos jest bez wątpienia obiektem unikatowym i ze względów bezpieczeństwa nie ma absolutnie żadnej możliwości, aby opuścił muzealną gablotę, w której jest należycie zabezpieczony.

$\mathrm{Z}$ analogicznych powodów muzeum w Heraklionie odmawia wydania na potrzeby przeprowadzenia stosownych badań również brązowego toporu z Arkalochori. Tymczasem nieoficjalnie uważa się, że być może greccy naukowcy już coś istotnego $\mathrm{w}$ rozważanej materii wiedzą, w związku z czym władze muzeum w Heraklionie obawiają się potężnego skandalu, zapewne o zasięgu światowym, i w efekcie utraty pokaźnych wpływów finansowych od turystów, którzy nader licznie wciąż przybywają na Kretę, aby na własne oczy zobaczyć tak niezwykły i pod każdym względem intrygujący obiekt.

Warto jeszcze na zakończenie nadmienić, że istnieją również uzasadnione podejrzenia, iż pierwowzorem dla osoby, która dopuściła się fałszerstwa dysku z Fajstos, był tzw. ołowiany dysk z Magliano pochodzący prawdopodobnie z V wieku p.n.e. i zawierający 70 wyrazów w języku etruskim wyrytych również w formie spirali od jej brzegu ku środkowi (zob. L. Bonfante 1998.) Ołowiany dysk z Magliano został odkryty w 1883 i jest obecnie przechowywany w muzeum archeologicznym we Florencji. Wydaje się, że L. Pernier musiał wiedzieć o istnieniu dysku z Magliano, który jest przecież jednym z podstawowych zabytków zawierających dłuższe zapisy tekstów w języku etruskim. Rozważany obiekt stanowił prawdopodobnie inspirację do popełnionego przez L. Perniera w późniejszym okresie fałszerstwa dysku z Fajstos.

Obecnie definitywne ustalenie bądź wykluczenie autentyczności dysku z Fajstos wydaje się być sprawą wagi kluczowej. Sytuacja, w której będący prawdopodobnie falsyfikatem dysk z Fajstos od ponad stu lat zwodzi całe rzesze uczonych, przyczyniając się w istotny sposób do marnowania ich potencjału badawczego i jakże cennych zasobów czasowych, nie powinna już dłużej w żadnym wypadku mieć miejsca. Niestety, nic nie wskazuje na to, aby w tej kwestii w najbliższym czasie cokolwiek miało 
ulec zasadniczej zmianie. W związku z powyższym badacze zdani są jedynie na snucie różnego rodzaju poszlak i poszukiwanie dowodów natury pośredniej. W opinii autora nieco światła na zagadnienia związane z dyskiem z Fajstos może rzucić właściwie przeprowadzona analiza statystyczna. Przede wszystkim należy podjąć próbę ustalenia, stosując metody wypracowane przez statystykę, czy dysk z Fajstos istotnie zawiera jakikolwiek tekst zapisany w pewnym języku naturalnym.

\section{Dysk z Fajstos jako obiekt badań statystycznych}

Na dysku z Fajstos odciśniętych zostało w sumie 241 znaków, przy czym nieliczne źródła podają, że jest ich o jeden więcej, czyli 242. Występująca w tej materii rozbieżność bierze się stąd, że na dysku z Fajstos w przypadku wyrazu oznaczonego symbolem A8 występuje miejsce, w którym z pewnością został pierwotnie odciśnięty jakiś znak, lecz następnie został on z jakichś nieznanych powodów zamazany (być może podczas pisania tekstu na dysku po prostu doszło do pomyłki - zresztą takich miejsc, w których dokonano korekty pierwotnie odciśniętych symboli można doszukać się tam znacznie więcej). Na stronie A dysku z Fajstos odciśnięto łącznie 122 znaki, a na stronie B znaków jest 119, przy czym występuje aż 49 różnych typów znaków (zob. A. Kondratow 1988).

Pierwotnie sądzono, że stronę A dysku należy czytać w pierwszej kolejności, a następnie tekst przechodzi na stronę $B$, jednak obecnie tego typu przypuszczenia wydają się nie być już niczym uzasadnione. Jak już uprzednio wspomniano odciśnięte na dysku z Fajstos znaki ułożone są na obu jego stronach w formie spirali. Dość powszechnie przyjmuje się, że dysk z Fajstos należy czytać posuwając się od jego brzegu ku środkowi, gdyż właśnie w takiej kolejności odciśnięte zostały kolejne znaki (wiemy to stąd, że niektóre z nich nieco zachodzą na siebie). Znajdujące się na dysku z Fajstos znaki zostały podzielone za pomocą pionowych linii na krótkie sekcje, które liczą od dwóch do siedmiu znaków, przy czym sekcje te najczęściej utożsamiane są z poszczególnymi wyrazami odciśniętego na dysku tekstu. Łącznie na dysku z Fajstos występuje 61 wyrazów, z czego 31 na stronie A i 30 na stronie B. W przypadku osiemnastu wyrazów na ich końcu umieszczono na dole ukośną kreskę. W tym wypadku nasuwa się tutaj analogia $\mathrm{z}$ indyjskim pismem dewanagari, którym obecnie zapisywany jest między innymi język hindi, a w przeszłości zapisywano nim główny język starożytnych Indii - sanskryt (zob. M. Mejor 2000). Występujące w przypadku pisma dewanagari na końcu wyrazów ukośne kreski nazywane są wiramami, a ich rola sprowadza się do kasowania wymowy występujących na końcu tego rodzaju wyrazów samogłosek (zob. D. Stasik 1998).

Powszechnie przyjmuje się, że tekst odciśnięty na dysku z Fajstos został zapisany z wykorzystaniem jakiegoś rodzaju pisma sylabicznego. Tego rodzaju forma zapisu języka była powszechnie stosowana w starożytności, czego przykładem są chociażby znane z Krety systemy pism linearnych A i B. Pismem sylabicznym zapisywano także dialekt starożytnego języka greckiego, który używany był na Cyprze (zob. J. Chadwick 1998). Również obecnie pisma sylabiczne są silnie rozpowszechnione w Azji i służą, między innymi, do zapisu większości języków używanych na terytorium Indii. W ten sposób zapisywane są języki takie jak na przykład nepalski, bengalski, 
syngaleski, tybetański, birmański, tajski, laotański i khmerski (zob. A. F. Majewicz 1998).

Głównym argumentem przemawiającym za sylabiczną formą zapisu dysku z Fajstos jest liczba użytych w tym celu różnych typów znaków, których, jak już wcześniej wspomniano, jest w sumie 45. Wobec „szczupłości” zapisanego na dysku z Fajstos tekstu (w sumie jest to zaledwie 61 wyrazów i 241 znaków pisma) przypuszczać należy, że wszystkich znaków występujących w rozważanym systemie pisma musiało być nieco więcej. Stosując odpowiednie metody statystyczne i analizując liczbę nowych znaków pojawiających się w każdej kolejnej dziesiątce znaków, można szacować, że wszystkich znaków w rozważnym systemie pisma mogło być około 60 (zob. Y. Duhoux 2000). Uzyskana liczba znaków jest stanowczo zbyt duża jak na system pisma alfabetycznego (na przykład w alfabecie łacińskim występuje zaledwie 26 podstawowych znaków pisma, a podobne liczby spotykane są także w przypadku innego rodzaju alfabetów, takich jak chociażby etruski, oskijski, grecki, hebrajski, fenicki, aramejski czy arabski). Rozważana liczba jest też zdecydowanie zbyt mała jak na system pisma obrazkowego - na przykład japoński system pisma kanji zawiera aż 1945 znaków podstawowych (zob. B. Nowak 1995). W związku z powyższym wydaje się, że jedyną sensowną propozycją jest przyjęcie, że do zapisu tekstu odciśniętego na glinianym dysku z Fajstos wykorzystano jakąś formę zapisu sylabicznego.

Dysk z Fajstos był już w przeszłości obiektem różnego rodzaju badań statystycznych (zob. M. P. Jackson 1999). Przede wszystkim w trakcie tego typu badań analizowano częstość pojawiania się poszczególnych znaków, w związku z czym ustalono, że najbardziej rozpowszechnionym znakiem, który występuje aż 19 razy, jest znak przedstawiający głowę wojownika w hełmie z pióropuszem (znak nr 2). Co ciekawe, podobny znak pojawia się aż pięć razy na brązowym toporze z Arkalochori oraz być może jeden raz na inskrypcji wykutej na kamiennym ołtarzu z Mali, chociaż w tym wypadku podobieństwo jest jedynie częściowe. Ponadto siedem typów znaków odciśniętych na dysku z Fajstos to tzw. hapax legomena, czyli w całym tekście pojawiają się zaledwie jedynie raz, a zatem o statystycznej częstości ich występowania nie można w zasadzie niczego pewnego powiedzieć. Jak już uprzednio nadmieniono, dość poważnym problemem jest „szczupłość” tekstu odciśniętego na glinianym dysku z Fajstos, co utrudnia prowadzenie jakichkolwiek analiz natury statystycznej i stawia pod dużym znakiem zapytania wiarygodność uzyskanych tą drogą wyników.

Dotychczas opublikowanych zostało już kilka prac, których autorzy stosowali metody wypracowane $\mathrm{w}$ ramach statystyki i probabilistyki w celu wyciągnięcia wniosków dotyczących natury tekstu odciśniętego na dysku z Fajstos. Między innymi A.T. Cate zwrócił uwagę na fakt, że w zasadzie wszystkie znaki odciśnięte za pomocą stempelków na dysku mają identyczną orientację przestrzenną. Jedyne wyjątki w tym względzie dotyczą zaledwie trzech typów znaków, do których zaliczyć można znak przedstawiający wizerunek wygarbowanej wołowej skóry (znak nr 27), głowę kota (znak nr 29) oraz ptaka w locie - być może orła (znak nr 31). Wymienione znaki występują w różnych miejscach dysku w pozycjach obróconych o pewne wartości kątów względem pozycji wyjściowej. A.T. Cate postawił ważne pytanie, czy tego ro- 
dzaju anomalie mogą być jedynie dziełem przypadku, czy też różne orientacje przestrzenne wybranych znaków zostały wprowadzone w sposób intencjonalny (zob. A.T. Cate 2013). Stworzony przez A.T. Cate złożony model probabilistyczny oraz uzyskane wyniki odpowiednio przeprowadzonych symulacji komputerowych w zdecydowany sposób wykluczają przypadkowe pojawienie się rozważanych rotacji wyróżnionych trzech typów znaków. Wypływa stąd ważny wniosek odnośnie poczynionych dotychczas prób odczytania dysku z Fajstos. Mianowicie, każda propozycja odczytu, która już na wstępie nie ma być całkowicie zdyskwalifikowana, musi uwzględniać fakt, że niektóre ze znaków odciśniętych na dysku występują w różnych orientacjach przestrzennych, co oczywiście powinno mieć wpływ na ich wartości fonetyczne bądź ewentualne funkcje znaczeniowe. Wydaje się, że jak dotychczas żadna z zaproponowanych prób odczytania dysku z Fajstos nie spełnia wymienionego warunku, co bardzo mocno podważa ich wiarygodność.

Z kolei we wcześniejszej swojej pracy A.T. Cate dopatrzył się występowania na dysku z Fajstos swego rodzaju wzorców geometrycznych (zob. A.T. Cate 2011). Na przykład znak przedstawiający głowę wojownika w hełmie z pióropuszem (znak nr 2) bardzo często umiejscowiony jest w ten sposób, że kilka tego rodzaju znaków umieszczonych jest jeden nad drugim na bezpośrednio przylegających do siebie zwojach spirali, tworząc odcinki linii prostej. Podobnie znaki przedstawiające wygarbowaną wołową skórę (znak nr 27) w dwóch miejscach tworzą trójkąty, będąc umieszczonymi w ich wierzchołkach. Przeprowadzone przez A.T. Cate eksperymenty numeryczne typu Monte Carlo definitywnie wykluczają przypadkowe pojawienie się tego rodzaju wzorców geometrycznych na powierzchni dysku. Wynika z tego ważny wniosek, który w skrócie sprowadza się do tego, że w przypadku dysku z Fajstos najprawdopodobniej nie mamy do czynienia ze zwykłym tekstem o charakterze linearnym, a jedynie pomiędzy znakami występującymi na sąsiadujących ze sobą pozycjach w przylegających bezpośrednio do siebie zwojach spirali zachodzą pewnego typu związki natury semantycznej. Taki stan rzeczy sprawia, że wszelkie dotychczasowe próby odczytania dysku z Fajstos, które w ogóle nie uwzględniają tego typu relacji przestrzennych, zachodzących pomiędzy wyszczególnionymi grupami znaków, są po prostu niewiarygodne i muszą zostać z zasady już na samym wstępie odrzucone.

Autor niniejszego artykułu poddał analizie statystycznej innego rodzaju cechy charakterystyczne inskrypcji odciśniętej na dysku z Fajstos, do których zalicza się, między innymi, długości poszczególnych wyrazów, wyrażone w liczbie odciśniętych znaków. Jak już uprzednio nadmieniono, tekst na dysku z Fajstos nie jest zbyt długi i zawiera zaledwie 61 wyrazów (oczywiście przy założeniu, że pionowe kreski dzielą tekst dysku na wyrazy, co jest dość powszechnie akceptowaną hipotezą). Ogólnie uważa się, że pełnoprawne wnioski natury statystycznej można wyciągać dopiero w przypadku analizy zbiorów zawierających przynajmniej sto elementów (zob. L. Gajek / M. Kałuszka 1996). Niestety, dysk z Fajstos zawiera nieco mniejszą liczbę wyrazów, w związku z czym do uzyskanych metodami statystycznymi wyników należy w tym wypadku podchodzić zapewne ze znaczną dozą ostrożności. 


\section{Analiza długości wyrazów odciśniętych na dysku z Fajstos}

Jak już na początku wspomniano, poszczególne wyrazy na dysku z Fajstos zawierają od dwóch do siedmiu znaków. Pełna statystyka wyrażona w procentowej częstości występowania wyrazów o różnej długości, rozumianej jako liczba odciśniętych na glinianym dysku znaków, została zamieszczona w tabeli 1.

\begin{tabular}{|l|l|l|l|l|l|}
\hline Liczba znaków w wyrazie & $<\mathbf{3}$ & $\mathbf{3}$ & $\mathbf{4}$ & $\mathbf{5}$ & $>\mathbf{5}$ \\
\hline $\begin{array}{l}\text { Częstość występowania wyrazów o } \\
\text { danej liczbie znaków }\end{array}$ & $9,83 \%$ & $26,23 \%$ & $36,07 \%$ & $19,67 \%$ & $8,20 \%$ \\
\hline
\end{tabular}

Tabela 1. Wyrażona w procentach częstość występowania wyrazów o różnej liczbie znaków, wyznaczona dla dysku z Fajstos traktowanego jako całość (strony A i B dysku).

Jak wynika z zawartości tabeli 1, dysk z Fajstos zawiera stosunkowo najwięcej wyrazów, do zapisu których wykorzystano cztery znaki (36,07\%). Sporo jest także wyrazów składających się z trzech znaków (26,23\%) i pięciu znaków $(19,67 \%)$. Z kolei bardzo krótkie wyrazy, w przypadku których odciśnięto w glinie mniej niż trzy znaki, są nieliczne i stanowią zaledwie 9,83\% wszystkich znaków. Analogicznie, wyrazów długich, zawierających więcej niż pięć znaków, jest jeszcze mniej, ponieważ stanowią jedynie 8,20\% wszystkich znaków odciśniętych na dysku.

W celu wyrobienia sobie poglądu odnośnie charakteru systemu pisma zastosowanego w przypadku dysku z Fajstos warto jest dokonać jego porównania z innym rodzajem systemu zapisu sylabicznego. W tabeli 2 zamieszczono statystykę dotycząca procentowej częstości występowania wyrazów o różnej długości, wyznaczoną dla tekstów zapisanych we współczesnym języku hebrajskim. Zarówno w przeszłości, jak i obecnie język hebrajski zapisywany jest za pomocą specjalnego alfabetu, jednakże w jego przypadku stosowany jest specyficzny sposób zapisu wyrazów. Mianowicie, bezpośredniemu zapisowi podlegają jedynie występujące w danym wyrazie spółgłoski oraz samogłoski długie, natomiast wartości fonetycznych samogłosek krótkich trzeba się po prostu domyślić, co w przypadku osoby znającej biegle język hebrajski bynajmniej nie stanowi większego problemu. Z kolei w przypadku tekstów szkolnych, służących do nauki czytania, oraz w przypadkach wątpliwych (na przykład przy zapisie nazw obcojęzycznych) stosowana jest tzw. wokalizacja zapisu, gdzie w przypadku każdej spółgłoski kodowana jest (za pomocą skomplikowanego systemu kropek i kresek umieszczanych pod daną spółgłoską) występująca po niej samogłoska krótka (zob. M. Tomal 2000). W związku z powyższym zapis języka hebrajskiego, chociaż pozornie oparty na systemie alfabetycznym, sprowadza się de facto do systemu zapisu sylabicznego, gdyż kodowaniu podlegają całe sylaby (złożone ze spółgłoski i występującej bezpośrednio po niej samogłoski krótkiej), ewentualnie zapisywane są same samogłoski długie.

Zamieszczona w tabeli 2 statystyka dotycząca długości wyrazów języka hebrajskiego została wyznaczona w oparciu o losowo wybrane przez autora próbki tekstów zapisanych we współczesnym języku hebrajskim o łącznej długości liczącej 300 znaków alfabetu hebrajskiego. 


\begin{tabular}{|l|l|l|l|l|l|}
\hline Liczba znaków w wyrazie & $<\mathbf{3}$ & $\mathbf{3}$ & $\mathbf{4}$ & $\mathbf{5}$ & $>\mathbf{5}$ \\
\hline $\begin{array}{l}\text { Częstość występowania wyrazów } \\
\text { o danej liczbie znaków }\end{array}$ & $12,00 \%$ & $17,67 \%$ & $26,33 \%$ & $23,00 \%$ & $21,00 \%$ \\
\hline
\end{tabular}

Tabela 2. Wyrażona w procentach częstość występowania wyrazów o różnej liczbie znaków, wyznaczona dla współczesnego języka hebrajskiego.

Podobnie jak w przypadku dysku z Fajstos tabela 2 zawiera informację o procentowej częstości występowania we współczesnym języku hebrajskim wyrazów, do zapisu których wykorzystuje się mniej niż trzy znaki, dokładnie trzy znaki, dokładnie cztery znaki, dokładnie pięć znaków oraz więcej niż pięć znaków. Porównując tabelę 1 i tabelę 2 widać, że przedstawione w nich wartości różnią się nieco od siebie. Mianowicie, we współczesnym języku hebrajskim jest statystycznie znacznie więcej wyrazów, do zapisu których wykorzystuje się więcej niż pięć znaków alfabetu. Jednak z drugiej strony, zarówno w przypadku dysku z Fajstos, jak i w wypadku analizowanych tekstów zapisanych we współczesnym języku hebrajskim, statystycznie najwięcej występuje wyrazów, do zapisu których wykorzystywane są dokładnie cztery znaki.

W celu dokładniejszego porównania inskrypcji odciśniętej na dysku z Fajstos z językiem hebrajskim zdefiniowana została odległość pomiędzy tabelą 1 i tabelą 2 , którą należy rozumieć jako sumę wartości bezwzględnych różnic wielkości znajdujących się w odpowiadających sobie kolumnach rozważanych tabel. W związku z powyższym wzajemną odległość tabeli 1 i tabeli 2 należy obliczyć jako następującą sumę wartości bezwzględnych: $|9,83-12,00|+|26,23-17,67|+|36,07-26,33|+$ $|19,67-23,00|+|8,20-21,00|$. Po wykonaniu odpowiednich działań otrzymuje się wartość odległości pomiędzy tabelami 1 i 2 jako równą 36,60. Uzyskana wartość wzajemnej odległości rozważanych tabel 1 i 2 nie jest relatywnie zbyt wielka, jednak wyciąganie na tej podstawie wniosków, jakoby tekst odciśnięty na glinianym dysku z Fajstos został zapisany w jakimś starożytnym języku semickim, wydaje się na obecnym etapie badań zdecydowanie przedwczesne (zob. M. Gajer 2008).

Na rysunku 1 zamieszczono przetworzone przy użyciu odpowiednich komputerowych programów graficznych, przeznaczonych do obróbki map bitowych, fotografie przedstawiające obie strony dysku z Fajstos. Już po przeprowadzeniu pobieżnej analizy widać, że obie strony dysku z Fajstos w istotny sposób różnią się od siebie (zob. M. P. Jackson 2000). Tym, co przyciąga szczególną uwagę, jest aż dwunastokrotne występowanie na stronie A dysku sekwencji składającej się z dwóch znaków, którymi są znak przedstawiający głowę wojownika w hełmie z pióropuszem (znak nr 2) oraz znak przedstawiający wizerunek tarczy (znak nr 12). Z kolei w przypadku strony B dysku z Fajstos tego rodzaju sekwencja znaków pojawia się zaledwie jeden raz na samym początku odciśniętej tam inskrypcji. Na rysunku 1 miejsca wystąpień rozważanych sekwencji znaków zostały zaznaczone w przypadku obu stron dysku za pomocą czarnych okręgów. W związku z powyższym nasuwa się ważne pytanie, czy to, co zdaje się być widoczne już na pierwszy rzut oka, znajduje również pewne odzwierciedlenie w statystyce częstości występowania wyrazów zapisanych przy użyciu różnej liczby znaków. 


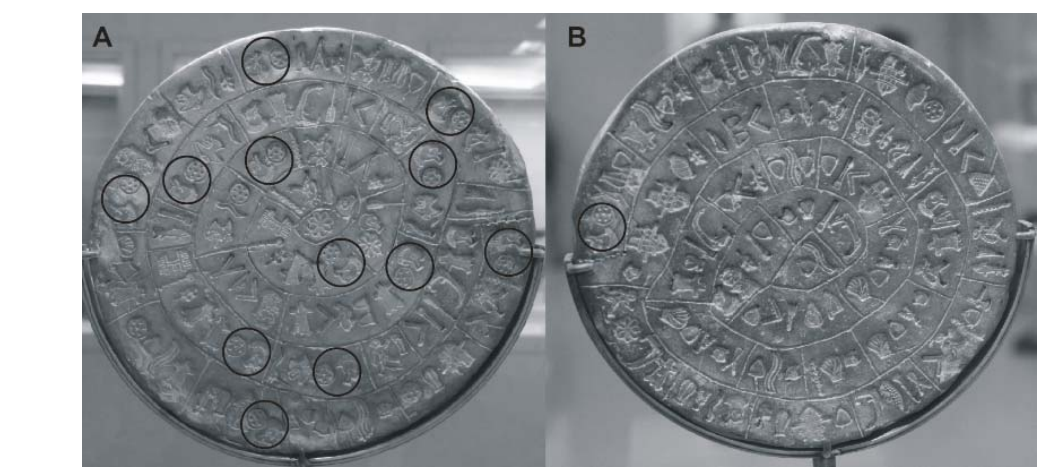

Rysunek 1. Strony A i B dysku z Fajstos z zaznaczonymi za pomoca czarnych okręgów powtarzającymi się sekwencjami znaków nr 2 i 12 (opracowanie własne).

W tabelach 3 i 4 zamieszczono informację odnośnie procentowej częstości występowania wyrazów, do zapisu których wykorzystano różną liczbę znaków, w przypadku odpowiednio strony A i strony B dysku z Fajstos.

\begin{tabular}{|l|l|l|l|l|l|}
\hline Liczba znaków w wyrazie & $<\mathbf{3}$ & $\mathbf{3}$ & $\mathbf{4}$ & $\mathbf{5}$ & $>\mathbf{5}$ \\
\hline $\begin{array}{l}\text { Częstość występowania wyrazów o } \\
\text { danej liczbie znaków }\end{array}$ & $16,13 \%$ & $29,03 \%$ & $25,81 \%$ & $12,90 \%$ & $16,13 \%$ \\
\hline
\end{tabular}

Tabela 3. Wyrażona w procentach częstość występowania wyrazów o różnej liczbie znaków, wyznaczona dla strony A dysku z Fajstos.

\begin{tabular}{|l|l|l|l|l|l|}
\hline Liczba znaków w wyrazie & $<\mathbf{3}$ & $\mathbf{3}$ & $\mathbf{4}$ & $\mathbf{5}$ & $>\mathbf{5}$ \\
\hline $\begin{array}{l}\text { Częstość występowania wyrazów o } \\
\text { danej liczbie znaków }\end{array}$ & $3,33 \%$ & $23,33 \%$ & $46,67 \%$ & $26,67 \%$ & $0,00 \%$ \\
\hline
\end{tabular}

Tabela 4. Wyrażona w procentach częstość występowania wyrazów o różnej liczbie znaków, wyznaczona dla strony $B$ dysku z Fajstos.

Analizując zawartości tabeli 3 i 4 widać, że dane statystyczne, ogólnie rzecz ujmując, potwierdzają to, co widoczne jest w zasadzie już nawet przy bardzo pobieżnej analizie powierzchni dysku z Fajstos, a mianowicie, iż obie jego strony różnią się w sposób istotny od siebie. Strona B dysku z Fajstos w porównaniu ze stroną A zawiera znacznie więcej wyrazów składających się dokładnie z czterech znaków, a poza tym w jej przypadku w ogóle nie występują wyrazy o większej długości niż pięć znaków. W przypadku strony B występuje tylko jeden wyraz zapisany za pomocą dokładnie dwóch znaków, podczas gdy na stronie A takich wyrazów jest aż pięć. Podobnie jak w przypadku tabel 1 i 2, i tu można w analogiczny sposób obliczyć odległość pomiędzy tabelami 3 i 4, która wynosi 69,26. Uzyskany wynik jest w pewnym sensie zaskakujący, ponieważ odległość pomiędzy stroną A i stroną B dysku z Fajstos okazuje się aż 1,89 razy większa niż odległość dysku z Fajstos (traktowanego jako całość) od losowo wybranych przez autora próbek tekstu zapisanego we współczesnym języku hebrajskim.

Uzyskany wynik pozwala postawić kolejne ważne pytanie, czy w przypadku dysku z Fajstos nie mamy aby do czynienia z tekstem bilingwicznym, a zatem czy strony A i B dysku nie są po prostu zapisane w dwóch różnych językach. Jednak po 
bardziej szczegółowej analizie tego rodzaju hipoteza wydaje się raczej mało prawdopodobna, chociaż niekiedy pojawia się gdzieniegdzie w literaturze przedmiotu (zob. Y. Duhoux 2000). Przede wszystkim należy uwzględnić fakt, że obie strony dysku zasadniczo zostały zapisane przy użyciu tego samego rodzaju zestawu znaków. Owszem, na obu stronach dysku występują pewne znaki, których w ogóle brak jest po stronie przeciwnej, ale nie są to bynajmniej przypadki zbyt liczne, a znaki te najczęściej należą do wspomnianej uprzednio kategorii typu hapax legomena. Poza tym sekwencja znaków nr 2 i 12, która pojawia się aż dwunastokrotnie na stronie A dysku z Fajstos, występuje również jeden raz na jego stronie B, co świadczy o tym, że w przypadku obu stron dysku mamy prawdopodobnie do czynienia z tym samym sposobem kodowania informacji.

Według pewnych teorii sekwencja znaków nr 2 i 12 pełni rolę tzw. determinatywu, który określa wojownika. Bezpośrednio po tego rodzaju determinatywie powinno zatem znajdować się imię danego wojownika (zob. A. Kondratow 1988). W związku z powyższym, analizując statystyczne prawidłowości dotyczące procentowej zawartości wyrazów o różnej liczbie znaków, należałoby wszystkich występujących na obu stronach dysku trzynastu sekwencji znaków nr 2 i 12 po prostu w ogóle nie uwzględniać, ponieważ znaki te nie stanowią części składowej wyrazów, które bezpośrednio poprzedzają. W tabelach 5 i 6 zamieszczono informację o procentowej częstości występowania wyrazów o różnej liczbie znaków w przypadku nieuwzględnienia sekwencji znaków nr 2 i 12.

\begin{tabular}{|l|l|l|l|l|l|}
\hline Liczba znaków w wyrazie & $<\mathbf{3}$ & $\mathbf{3}$ & $\mathbf{4}$ & $\mathbf{5}$ & $>\mathbf{5}$ \\
\hline $\begin{array}{l}\text { Częstość występowania wyrazów o } \\
\text { danej liczbie znaków }\end{array}$ & $32,25 \%$ & $41,94 \%$ & $9,68 \%$ & $9,68 \%$ & $6,45 \%$ \\
\hline
\end{tabular}

Tabela 5. Wyrażona w procentach częstość występowania wyrazów o różnej liczbie znaków, wyznaczona dla strony A dysku z Fajstos w przypadku nieuwzględnienia sekwencji znaków nr 2 i 12 w poszczególnych wyrazach.

\begin{tabular}{|l|l|l|l|l|l|}
\hline Liczba znaków w wyrazie & $<\mathbf{3}$ & $\mathbf{3}$ & $\mathbf{4}$ & $\mathbf{5}$ & $>\mathbf{5}$ \\
\hline $\begin{array}{l}\text { Częstość występowania wyrazów o } \\
\text { danej liczbie znaków }\end{array}$ & $3,33 \%$ & $26,67 \%$ & $46,67 \%$ & $23,33 \%$ & $0,00 \%$ \\
\hline
\end{tabular}

Tabela 6. Wyrażona w procentach częstość występowania wyrazów o różnej liczbie znaków, wyznaczona dla strony $B$ dysku z Fajstos w przypadku nieuwzględnienia sekwencji znaków nr 2 i 12 w poszczególnych wyrazach.

Wyznaczona w sposób analogiczny jak uprzednio wzajemna odległość dzieląca tabele 5 i 6 wynosi aż 101,28. Uzyskany wynik jest całkowitym zaskoczeniem, ponieważ w tym wypadku odległość dzieląca stronę A od strony B dysku zamiast zmaleć, istotnie wzrosła i jest aż 2,77 razy większa od odległości dzielącej dysk z Fajstos (traktowany jako całość) od losowo wybranych przez autora fragmentów tekstów zapisanych we współczesnym języku hebrajskim. Oczywiście, uzyskany rezultat stawia również pod mocnym znakiem zapytania hipotezę, w myśl której sekwencja znaków nr 2 i 12 stanowi determinatyw oznaczający wojownika.

W związku z powyższym, przeprowadzając analizy statystyczne oddzielnie dla strony A i B dysku z Fajstos, można byłoby postąpić w nieco inny sposób. Mianowicie, można byłoby w ogóle nie uwzględniać wyrazów, na początku których występuje 
sekwencja znaków nr 2 i 12. W takim wypadku należałoby przyjąć, że strona A dysku zawiera jedynie 19 wyrazów, a strona B dysku 29 wyrazów. Uzyskane wyniki analizy statystycznej przeprowadzonej dla rozpatrywanego powyżej przypadku zamieszczono w tabelach 7 i 8 .

\begin{tabular}{|l|l|l|l|l|l|}
\hline Liczba znaków w wyrazie & $<\mathbf{3}$ & $\mathbf{3}$ & $\mathbf{4}$ & $\mathbf{5}$ & $>\mathbf{5}$ \\
\hline $\begin{array}{l}\text { Częstość występowania wyrazów o } \\
\text { danej liczbie znaków }\end{array}$ & $26,32 \%$ & $47,37 \%$ & $15,79 \%$ & $0,00 \%$ & $10,52 \%$ \\
\hline
\end{tabular}

Tabela 7. Wyrażona w procentach częstość występowania wyrazów o różnej liczbie znaków, wyznaczona dla strony A dysku z Fajstos w przypadku nieuwzględnienia wyrazów zawierających sekwencję znaków nr 2 i 12.

\begin{tabular}{|l|l|l|l|l|l|}
\hline Liczba znaków w wyrazie & $<\mathbf{3}$ & $\mathbf{3}$ & $\mathbf{4}$ & $\mathbf{5}$ & $>\mathbf{5}$ \\
\hline $\begin{array}{l}\text { Częstość występowania wyrazów o } \\
\text { danej liczbie znaków }\end{array}$ & $3,45 \%$ & $24,14 \%$ & $48,27 \%$ & $24,14 \%$ & $0,00 \%$ \\
\hline
\end{tabular}

Tabela 8. Wyrażona w procentach częstość występowania wyrazów o różnej liczbie znaków, wyznaczona dla strony B dysku z Fajstos w przypadku nieuwzględnienia wyrazów zawierających sekwencję znaków nr 2 i 12.

Wyznaczona wzajemna odległość pomiędzy tabelami 7 i 8 wynosi aż 113,24, a zatem w rozważanym przypadku odległość pomiędzy stronami A i B dysku z Fajstos okazała się być jeszcze większa niż uprzednio, przewyższając 3,09 razy odległość pomiędzy dyskiem z Fajstos (traktowanym jako całość) a losowo wybranymi przez autora próbkami tekstów zapisanych we współczesnym języku hebrajskim.

\section{Analizy porównawcze przeprowadzone dla języka hebrajskiego}

Zaprezentowane w poprzednim punkcie analizy statystyczne wykazały znaczne różnice występujące pomiędzy stronami A i B dysku z Fajstos. W związku z powyższym nasuwa się ważne pytanie, czy tego rodzaju anomalie statystyczne są czymś powszechnie występującym w przypadku analizy krótkich fragmentów tekstów, do zapisu których wykorzystywany jest system sylabiczny. W celu uzyskania odpowiedzi na tak postawione pytanie autor przeprowadził badania porównawcze $\mathrm{w}$ oparciu $\mathrm{o}$ dziesięć wybranych losowo próbek tekstów zapisanych we współczesnym języku hebrajskim, przy czym każda z badanych próbek zawierała dokładnie 30 wyrazów. W tabelach 9-18 zawarto uzyskane wyniki, podające procentową zawartość w badanych próbkach tekstów wyrazów o różnej długości, wyrażonej w liczbie znaków alfabetu hebrajskiego potrzebnych do ich zapisu.

\begin{tabular}{|l|l|l|l|l|l|}
\hline Liczba znaków w wyrazie & $<\mathbf{3}$ & $\mathbf{3}$ & $\mathbf{4}$ & $\mathbf{5}$ & $>\mathbf{5}$ \\
\hline $\begin{array}{l}\text { Częstość występowania wyrazów } \\
\text { o danej liczbie znaków }\end{array}$ & $10,00 \%$ & $6,67 \%$ & $20,00 \%$ & $23,33 \%$ & $40,00 \%$ \\
\hline
\end{tabular}

Tabela 9. Wyrażona w procentach częstość występowania wyrazów o różnej liczbie znaków, wyznaczona dla współczesnego języka hebrajskiego (próbka tekstu nr 1).

\begin{tabular}{|l|l|l|l|l|l|}
\hline Liczba znaków w wyrazie & $<\mathbf{3}$ & $\mathbf{3}$ & $\mathbf{4}$ & $\mathbf{5}$ & $>\mathbf{5}$ \\
\hline $\begin{array}{l}\text { Częstość występowania wyrazów } \\
\text { o danej liczbie znaków }\end{array}$ & $10,00 \%$ & $23,33 \%$ & $23,33 \%$ & $20,00 \%$ & $23,34 \%$ \\
\hline
\end{tabular}

Tabela 10. Wyrażona w procentach częstość występowania wyrazów o różnej liczbie znaków, wyznaczona dla współczesnego języka hebrajskiego (próbka tekstu nr 2). 


\begin{tabular}{|l|l|l|l|l|l|}
\hline Liczba znaków w wyrazie & $<\mathbf{3}$ & $\mathbf{3}$ & $\mathbf{4}$ & $\mathbf{5}$ & $>\mathbf{5}$ \\
\hline $\begin{array}{l}\text { Częstość występowania wyrazów } \\
\text { o danej liczbie znaków }\end{array}$ & $10,00 \%$ & $16,67 \%$ & $20,00 \%$ & $30,00 \%$ & $23,33 \%$ \\
\hline
\end{tabular}

Tabela 11. Wyrażona w procentach częstość występowania wyrazów o różnej liczbie znaków, wyznaczona dla wspótczesnego języka hebrajskiego (próbka tekstu nr 3).

\begin{tabular}{|l|l|l|l|l|l|}
\hline Liczba znaków w wyrazie & $<\mathbf{3}$ & $\mathbf{3}$ & $\mathbf{4}$ & $\mathbf{5}$ & $>\mathbf{5}$ \\
\hline $\begin{array}{l}\text { Częstość występowania wyrazów } \\
\text { o danej liczbie znaków }\end{array}$ & $20,00 \%$ & $30,00 \%$ & $13,33 \%$ & $30,00 \%$ & $6,67 \%$ \\
\hline
\end{tabular}

Tabela 12. Wyrażona w procentach częstość występowania wyrazów o różnej liczbie znaków, wyznaczona dla wspótczesnego języka hebrajskiego (próbka tekstu nr 4).

\begin{tabular}{|l|l|l|l|l|l|}
\hline Liczba znaków w wyrazie & $\mathbf{3}$ & $\mathbf{3}$ & $\mathbf{4}$ & $\mathbf{5}$ & $>\mathbf{5}$ \\
\hline $\begin{array}{l}\text { Częstość występowania wyrazów } \\
\text { o danej liczbie znaków }\end{array}$ & $3,33 \%$ & $13,33 \%$ & $43,34 \%$ & $10,00 \%$ & $30,00 \%$ \\
\hline
\end{tabular}

Tabela 13. Wyrażona w procentach częstość występowania wyrazów o różnej liczbie znaków, wyznaczona dla wspótczesnego języka hebrajskiego (próbka tekstu nr 5).

\begin{tabular}{|l|l|l|l|l|l|}
\hline Liczba znaków w wyrazie & $<\mathbf{3}$ & $\mathbf{3}$ & $\mathbf{4}$ & $\mathbf{5}$ & $>\mathbf{5}$ \\
\hline $\begin{array}{l}\text { Częstość występowania wyrazów } \\
\text { o danej liczbie znaków }\end{array}$ & $13,33 \%$ & $13,33 \%$ & $23,34 \%$ & $30,00 \%$ & $20,00 \%$ \\
\hline
\end{tabular}

Tabela 14. Wyrażona w procentach częstość występowania wyrazów o różnej liczbie znaków, wyznaczona dla współczesnego języka hebrajskiego (próbka tekstu nr 6).

\begin{tabular}{|l|l|l|l|l|l|}
\hline Liczba znaków w wyrazie & $\mathbf{3}$ & $\mathbf{3}$ & $\mathbf{4}$ & $\mathbf{5}$ & $>\mathbf{5}$ \\
\hline $\begin{array}{l}\text { Częstość występowania wyrazów } \\
\text { o danej liczbie znaków }\end{array}$ & $20,00 \%$ & $16,67 \%$ & $26,67 \%$ & $23,33 \%$ & $13,33 \%$ \\
\hline
\end{tabular}

Tabela 15. Wyrażona w procentach częstość występowania wyrazów o różnej liczbie znaków, wyznaczona dla wspótczesnego języka hebrajskiego (próbka tekstu $n r$ 7).

\begin{tabular}{|l|l|l|l|l|l|}
\hline Liczba znaków w wyrazie & $<\mathbf{3}$ & $\mathbf{3}$ & $\mathbf{4}$ & $\mathbf{5}$ & $>\mathbf{5}$ \\
\hline $\begin{array}{l}\text { Częstość występowania wyrazów } \\
\text { o danej liczbie znaków }\end{array}$ & $10,00 \%$ & $26,67 \%$ & $23,33 \%$ & $26,67 \%$ & $13,33 \%$ \\
\hline
\end{tabular}

Tabela 16. Wyrażona w procentach częstość wystepowania wyrazów o różnej liczbie znaków, wyznaczona dla wspótczesnego języka hebrajskiego (próbka tekstu nr 8).

\begin{tabular}{|l|l|l|l|l|l|}
\hline Liczba znaków w wyrazie & $<\mathbf{3}$ & $\mathbf{3}$ & $\mathbf{4}$ & $\mathbf{5}$ & $>\mathbf{5}$ \\
\hline $\begin{array}{l}\text { Częstość występowania wyrazów } \\
\text { o danej liczbie znaków }\end{array}$ & $0,00 \%$ & $20,00 \%$ & $33,33 \%$ & $20,00 \%$ & $26,67 \%$ \\
\hline
\end{tabular}

Tabela 17. Wyrażona w procentach częstość występowania wyrazów o różnej liczbie znaków, wyznaczona dla wspótczesnego języka hebrajskiego (próbka tekstu nr 9).

\begin{tabular}{|l|l|l|l|l|l|}
\hline Liczba znaków w wyrazie & $<\mathbf{3}$ & $\mathbf{3}$ & $\mathbf{4}$ & $\mathbf{5}$ & $>\mathbf{5}$ \\
\hline $\begin{array}{l}\text { Częstość występowania wyrazów } \\
\text { o danej liczbie znaków }\end{array}$ & $23,33 \%$ & $10,00 \%$ & $36,67 \%$ & $16,67 \%$ & $13,33 \%$ \\
\hline
\end{tabular}

Tabela 18. Wyrażona w procentach częstość występowania wyrazów o różnej liczbie znaków, wyznaczona dla wspótczesnego języka hebrajskiego (próbka tekstu nr 10).

Z kolei wyniki analiz porównawczych przeprowadzonych pomiędzy próbkami tekstów zapisanych we współczesnym języku hebrajskim zamieszczono w tabeli 19. 


\begin{tabular}{|l|l|l|l|l|l|l|l|l|l|}
\hline & nr 2 & nr 3 & nr 4 & nr 5 & nr 6 & nr 7 & nr 8 & nr 9 & nr 10 \\
\hline nr 1 & 39,98 & 33,34 & 80,00 & 60,00 & 40,00 & 53,34 & 53,34 & 53,32 & 66,66 \\
\hline nr 2 & & 20,00 & 53,34 & 53,34 & 26,68 & 33,34 & 20,02 & 26,66 & 53,34 \\
\hline nr 3 & & & 46,66 & 60,02 & 13,34 & 33,34 & 26,66 & 40,00 & 60,00 \\
\hline nr 4 & & & & 106,68 & 46,68 & 40,00 & 33,32 & 80,00 & 66,66 \\
\hline nr 5 & & & & & 59,99 & 66,67 & 73,35 & 33,33 & 53,34 \\
\hline nr 6 & & & & & & 26,68 & 26,68 & 46,66 & 46,66 \\
\hline nr 7 & & & & & & & 26,68 & 46,66 & 26,66 \\
\hline nr 8 & & & & & & & & 46,68 & 53,35 \\
\hline nr 9 & & & & & & & & & 53,34 \\
\hline
\end{tabular}

Tabela 19. Zestawienie wzajemnych odległości pomiędzy analizowanymi próbkami tekstów zapisanych we współczesnym języku hebrajskim.

Jak wynika z zawartości tabeli 19, rozpiętość pomiędzy uzyskanymi wynikami jest znaczna, w związku z czym odległość pomiędzy badanymi próbkami tekstów waha się w dość szerokich granicach od 13,34 (próbki nr 3 i 6) do 106,68 (próbki nr 4 i 5). Z kolei średnia wartość odległości pomiędzy analizowanymi próbkami tekstów zapisanych we współczesnym języku hebrajskim wynosi 46,82, czyli jest 0,68 razy mniejsza niż wynosi wyznaczona w sposób bezpośredni odległość pomiędzy stronami A i B dysku z Fajstos. Natomiast w przypadku pominięcia sekwencji znaków nr 2 i 12 lub całych wyrazów zawierających rozważaną sekwencję znaków wartość rozpatrywanego stosunku odległości jest jeszcze mniejsza i wynosi odpowiednio 0,46 i 0,41 .

\section{Wnioski końcowe}

Słynny dysk z Fajstos bez wątpienia pozostaje nadal niezwykle pasjonującą i pod każdym względem jakże intrygującą zagadką, której rozwiązanie zapewne nie będzie ani łatwe, ani oczywiste. W artykule pokazano, że ewentualny tekst odciśnięty na rozważanym glinianym dysku zdaje się wykazywać swego rodzaju anomalie statystyczne, ponieważ spodziewana wartość odległości pomiędzy stronami A i B dysku zapewne powinna być nieco mniejsza, jeżeli mielibyśmy mieć $\mathrm{w}$ rozpatrywanym wypadku do czynienia $z$ tekstem zapisanym pismem sylabicznym w pewnym języku naturalnym. Jednakże, wziąwszy pod uwagę fakt, że teksty odciśnięte na obu stronach dysku z Fajstos są bardzo krótkie (jest to zaledwie 31 i 30 wyrazów, znajdujących się odpowiednio na stronach A i B dysku), spontanicznego pojawienia się tego rodzaju anomalii statystycznych równie nie można definitywnie wykluczyć.

Jeżeli jednak jest tak, że rację ma właśnie J. M. Eisenberg, według którego dysk z Fajstos jest jedynie zwykłym przykładem bezczelnego fałszerstwa starożytnych obiektów, wówczas uzyskane przez autora wyniki mogłyby stanowić istotny argument przemawiający za potwierdzeniem postawionej w ten sposób tezy. Mianowicie, w przypadku dopuszczenia się przez L. Perniera fałszerstwa należałoby spodziewać się raczej odciśnięcia na dysku z Fajstos jakichś przypadkowych sekwencji znaków, które nie niosłyby ze sobą żadnej informacji, a zatem ich właściwości statystyczne powinny w istotny sposób odbiegać od tego, co występuje typowo w przypadku tekstów w językach naturalnych zapisanych pismem sylabicznym. 
Jednak ostateczne rozstrzygnięcie tego rodzaju wątpliwości mogą przynieść jedynie badania termoluminescencyjne, które są w stanie dość precyzyjnie wyznaczyć wartość przedziału czasu, który upłynął od momentu wypalenia materiałów ceramicznych (zob. J. M. Eisenberg 2008). W przypadku dysku z Fajstos tego rodzaju badania są w stanie jednoznacznie potwierdzić, czy obiekt ten ma około 4000 lat, czy zaledwie niewiele ponad 100. Niestety, dopóki stanowisko muzeum w Heraklionie pozostawać będzie w rozpatrywanej materii nieprzejednane, tak długo skazani będziemy jedynie na mgliste spekulacje i snucie wszelkiego rodzaju domysłów odnośnie natury i znaczenia ewentualnego przekazu zaszyfrowanego obustronnie na powierzchni tajemniczego dysku z Fajstos.

\section{Bibliografia}

Bonfante, L. (1998), Język etruski, Warszawa, Wydawnictwo RTW.

Bradshaw, A. (1977), The Overcuts on the Phaistos Disc, (w:) Kadmos, 16 (2), 99110.

Cate, A.T. (2011), Patterns on an Ancient Artifact: A coincidence?, (w:) Statistica Neerlandica, 65 (1), 116-124.

Cate, A.T. (2013), A Statistical Analysis of the Rotated Signs of the Phaistos Disc, (w:) Pioneer Journal of Theoretical and Applied Statistics, 6 (2), 81-88.

Chadwick, J. (1998), Pismo linearne B. Warszawa.

Ciechanowicz, J. (1996), Cień Minotaura, Warszawa, Państwowy Instytut Wydawniczy.

Duhoux, Y. (2000), How Not to Decipher the Phaistos Disc: A Review, (w:) American Journal of Archeology, 104, 597-600.

Eisenberg, J. M. (2008), The Phaistos Disc: A one Hundred-Year-Old Hoax?, (w:) Minerva July/ August, 9-24.

Gajek, L. / M. Kałuszka (1996), Wnioskowanie statystyczne. Warszawa.

Gajer, M. (2008), Zastosowanie metod lingwistyki komputerowej do analizy starożytnych inskrypcji, (w:) Informatyka Teoretyczna i Stosowana , 8 (14), 53-62.

Jackson, M. P. (1999), A Statistical Study of the Phaistos Disc, (w:) Kadmos, 38, 19 30.

Jackson, M. P. (2000), Structural Parallelism on the Phaistos Disc. A Statistical Analysis, (w:) Kadmos, 39, 57-71.

Kondratow, A. (1988), Zaginione cywilizacje. Warszawa.

Majewicz, A. F. (1989), Języki świata i ich klasyfikowanie. Warszawa.

Mejor, M. (2000), Sanskryt. Warszawa.

Nowak, B. (1995), Stownik znaków japońskich. Warszawa.

Popko, M. (1999), Ludy i języki starożytnej Anatolii. Warszawa.

Reczko, W. (2009), Analyzing and Dating the Structure of the Phaistos Disk, (w:) Archeological and Anthropological Sciences, 1, 241-245.

Stasik, D. (1998), Język hindi. Warszawa.

Tomal, M. (2000), Język hebrajski biblijny. Warszawa. 